\title{
The Development of Pilularia globulifera, L.
}

BY

DOUGLAS HOUGHTON CAMPBELL, Ph.D. •

With Plates XIII. XIV. XV.

THE Pteridophytes, standing as they do between the nonvascular plants and the Phanerogams, are in many ways of especial interest to the botanist, and since the first work of Hofmeister ${ }^{1}$ on their embryology, there has been a long series of works of greater or less value bearing upon the subject.

Owing to the imperfect methods of the earlier investigators, it was impossible to satisfactorily make out much that is rendered relatively easy by the employment of the more improved methods of to-day, this being particularly the case with the study of the early stages in the germinating spores of the heterosporous forms.

In undertaking the work, the results of which are embodied in the accompanying paper, two objects were had in view:Ist, the investigation of the life-history of Pilularia globulifera; and 2nd, to determine how far the paraffin imbeddingprocess was of practical application in the study of vegetable embryology. In regard to the first point, the results are given at length in the following pages, and will not be recapitulated here; touching the second, it will be sufficient to say that the perfection of the sections thus obtainable, and especially the fact that series of sections can be made, will convince any one who has seen it that this method, or at any rate some method of imbedding by which similar serial sections can be made, will in future be as essential for the study of the embryology of the higher plants as it has come to be regarded in

1 Hofmeister, Vergleichende Untersuchungen.

[Annals of Botany, Vol. II. No. VII. November 1888.] 


\section{Campbell.-On the development}

zoology. The old method of rendering the embryo transparent by caustic potash and similar violent agents, while it may enable one to get a general idea of the structure of an embryo, can never show with exactness the cell-arrangement in a many-celled embryo, owing to the inevitable confusion arising from trying to get optical sections where several superposed layers of cells are present. At the same time the structure of the cell-contents is absolutely destroyed by these means. With freehand sectioning it is impossible to get more than a very few sections, indeed seldom more than a single good one of a young embryo, and of course only a partial idea of its structure is thus obtainable.

Hofmeister's brief account of Pilularia ${ }^{1}$, while in some particulars correct, is on the whole very imperfect, and the same may be said of Hanstein's work ${ }^{2}$. The later work of Arcangeli ${ }^{3}$ is much better, but is also in several particulars, notably the development of the male prothallium and the earliest stages of the female prothallium also, far from complete, and his account of the development of the embryo, as well as the figures of the same, leave very much to be desired.

The material used in making the investigations here recorded was obtained from the botanical garden in Berlin, where, in the autumn of 1887 , Pilularia was growing luxuriantly and had formed great numbers of ripe fruits. These were gathered at different times up to the middle of December, and placed in ordinary unglazed earthen pans filled with earth. They were kept in the cold-house connected with the laboratory, and retained their vitality perfectly as long as the observations lasted, all that was necessary being to water them moderately from time to time. In this way an abundant supply of fresh material was kept on hand all winter. It was found that if the spores were allowed to become perfectly dry for any length of time, that many of them, especially the

1 Vergleichende Untersuchungen.

2 Pilulariae globuliferae generatio cum Marsilia comparata. Bonn, 1866 .

3 'Sulla Pilularia e Salvinia,' in Nuovo Giornale Botanico Italiano, viii. p. 320. 
macrospores, lost their power of germination. In order that the spores may germinate, it is necessary that they be brought into direct contact with water, and in order to facilitate this the fruit should be cut open, or if it has spontaneously opened, the tough membrane covering the sporangia should be partially removed. The fruit is then placed in a vessel of water, and at a temperature of from I $8^{\circ}-20^{\circ} \mathrm{C}$. from forty to forty-eight hours is usually sufficient for the complete formation of the prothallia and sexual organs. It was found convenient, however, in many cases to retard the development, and this was readily accomplished by keeping the water at a lower temperature. In this way it is possible to so regulate the germination that all stages can be obtained, a difficult matter where the development proceeds too rapidly. With fresh material the spores germinate almost without exception.

The fruit of Pilularia globulifera, as is well known, is a round body about $3 \mathrm{~mm}$. in diameter, at maturity protected by a hard dark-brown covering. It contains four chambers, each enclosing a single large sorus attached to the outer wall. The upper half of each sorus contains only microsporangia, while the lower half contains for the most part only macrosporangia, although sometimes an occasional microsporangium occurs. At maturity the fruit splits into four parts, but the sori remain covered with the brown membrane that separated the four chambers of the unopened fruit, this membrane being firm and more or less impervious to water. It was possibly a failure to remove this membrane that led Arcangeli to mistake the length of time required for the germination of the spores. If it is removed so as to allow water free access, the mucilaginous cell-walls of the sporangia absorb the water with great rapidity, and the spores are carried into the water surrounded by a soft mass of colorless jelly. Probably under natural conditions germination does not begin until the fruit has been open long enough for the covering membrane to become somewhat decayed, as the spores retain their vitality for months after the fruit is open if kept in slightly moistened earth in a cool place. 
The Microspores and Male Prothallium.

The spores are of the tetrahedral type, and the vertical diameter is considerably less than the transverse. The three radiating ridges where the spore was formerly in contact with the other members of the tetrad are very prominent, and mark the place where the episporium and exosporium rupture when the antheridium is mature.

Arcangeli ${ }^{1}$ succeeded in demonstrating the presence of a vegetative cell of the prothallium, but beyond this his observations were very incomplete, owing to the fact that he did not succeed in freeing the prothallium from the exosporium, but simply rendered the latter as transparent as possible. It is, however, possible to remove the exosporium entirely, and when this is done it is found that we have to do with a much more complicated structure than was supposed, and one whose development can be followed with a precision that is quite out of the question when the observations are hindered by the semi-opaque exosporium, which absolutely prevents a clear view of the interior of the spore, even when every available means is used to render it transparent. The spore contains much starch, and in the later stages it is sufficient to place the spores in a drop of water upon a glass slide and cover them with a cover-glass, and heat the slide over a flame until the water boils, when it will be found that the starch swells up sufficiently to rupture the outer coats of the spore and force out the young prothallium, surrounded only by the perfectly transparent endosporium. The prothallium is in no degree injured by this process and the dissolution of the starch is rather an advantage, as the cell-walls and nuclei are more easily studied than when the cells are filled with the opaque starch-granules.

In the earlier stages this simple process is not sufficient, and it is necessary to employ caustic potash in order to free the prothallium from the exosporium, but a very small amount must be used, and it must afterwards be thoroughly 
neutralized, and the preparation washed until every trace of it is removed. Before the potash is applied the spores must be thoroughly hardened in alcohol, or better a chromic acid mixture, either a I per cent. watery solution, or Flemming's mixture of chromic, acetic, and osmic acids, a thorough washing being requisite after use of either of the latter. After addition of the potash the slide is heated as before. If the prothallium is not completely set free, this can generally be accomplished by gently rubbing the cover-glass to and fro, but the potash should previously be as far as possible drawn off by means of blotting paper, and pure water run under the cover-glass. After a final washing, the preparation is neutralized with acetic or hydrochloric acid, and may then be stained with haematoxylin or some anilin color. Haematoxylin is preferable, as the preparation can then be preserved in dilute glycerine, which extracts anilin color at once or after a short time. Care must be taken with haematoxylin not to overstain, as the color deepens very much after the spores have lain in the glycerine for a short time.

According to Arcangeli ${ }^{1}$ there are but two primary coats to the spore, the outer one showing, however, a division into three layers. The outermost of these is composed of numerous fine papillae of irregular form, and more or less anastomosing so as to form an irregular network. Within this is a layer to which these papillae are attached, and lastly the exosporium proper, which he describes as 'sottilissimo,' 'very delicate,' while in reality it is of appreciable thickness and decidedly firm and resistent. All of these three layers react like cuticularized membranes, while the endosporium proper shows the reaction of cellulose. Besides these there is often to be seen, at least in chromic acid preparations, what appears to be a loosely-fitting, nearly transparent but well-defined membrane outside, the episporium. Arcangeli assumes that all the membranes are derived from the plasma of the mother-cell, but it is more than likely that, as in the spores of Marsilia ${ }^{2}$ and in

\footnotetext{
1 1. c., p. 327 .

2 Strasburger, Bau und Wachsthum der Zellhäutc.
} 
others more recently investigated, the episporium is derived from the epiplasma, and must therefore be regarded as an entirely independent membrane and not as a part of the exosporium.

The spore (Pl. XIII, Fig. I) contains an easily-demonstrable nucleus, and is filled with densely granular protoplasm in which, as we have already seen, are imbedded numerous starchgranules.

The first wall formed in the germinating microspore(Pl.XIII, Fig. 2) is at right angles to the shorter axis of the spore, and divides it into a small basal cell and a much larger upper one, the mother-cell of the antheridium. The basal cell frequently becomes further divided into two cells of very unequal size, which represent the vegetative part of the prothallium. In the mother-cell of the antheridium there is next formed a wall which corresponds to that formed in the mother-cell of the antheridium of the Polypodiaceae. It is more or less distinctly concave above, and may be funnel-shaped, meeting the basal wall (Pl. XIII, Figs. 3, 4m). This wall is followed by a dome-shaped wall whose base is in contact with it, but the upper part usually free and approximately concentric with the outer wall of the spore (Pl. XIII, Figs. 3, 4n), but not infrequently cases were observed where it was to a greater or less extent in contact with the endosporium, so that the cell thus formed has its wall in part made up of the endosporium (PI.XIII, Fig. 5). This cell is the central cell of the antheridium, and from it alone are derived the mother-cells of the spermatozoids. Finally a ring-shaped wall is formed at the top, constituting the cap-cell of the antheridium. The succession of walls in the mother-cell of the antheridium, as will be seen from the above statement, follows almost exactly that of the Polypodiaceae, and shows a much less reduced state of the antheridium than was supposed to be the case; indeed occasionally the vegetative part of the male prothallium of certain Polypodiaceae (e.g. Asplenium Filix-foemina) may be reduced to a single cell ${ }^{1}$, and

1 D. H. Campbell, The Prothallium of Ferns, in Botanical Gazette, 1885. 


$$
\text { of Pilularia globulifera, } L \text {. }
$$

the resemblance between such a reduced fern-prothallium and that of Pilularia is evident at a glance.

All the divisions in the central cell are by means of walls, there being no primordial cells formed as asserted by Hanstein $^{1}$ for Marsilia, and Arcangeli ${ }^{2}$ for Pilularia. The first wall is nearly vertical, but generally more or less inclined, and divides the central cell into two nearly equal cells (PI. XIII, Fig. 5). This stage is reached at a temperature of about $20^{\circ} \mathrm{C}$., in about ten hours from the time the spores are placed in water. Each of the two cells now divides by a wall at right angles to the first and also approximately vertical, so that the young antheridium at this stage, when seen from above, shows the central cell divided into four equal parts arranged like the quadrants of a circle (P1. XIII, Fig. 6). Each cell next divides by a horizontal wall, so that there are two strata of cells, each composed of four similar cells. The position of the succeeding walls appears to vary more or less, but in general the next wall formed in each of the eight cells seems to be generally nearly parallel to its outer wall (P1.XIII, Fig. IOb), thus dividing it into an inner and an outer cell. Each cell now divides once more, forming altogether thirty-two cells, the number of spermcells usually formed in the completed antheridium (PI. XIII, Fig. II). The whole process of division occupies not far from thirty hours at a temperature of $18^{\circ}$ to $20^{\circ} \mathrm{C}$., but of course varies slightly in individual cases. The nuclei of the central cells color very intensely with haematoxylin, but those of the wall-cells of the antheridium are apparently very deficient in chromatin, to judge from the difficulty of demonstrating them satisfactorily.

As already stated, it is an easy matter to free from the exosporium the full-grown male prothallium and antheridium by simply heating. The vegetative part of the prothallium (Pl. XIII, Fig. 13) is separated by a firm wall. Above this lies the Jarge basal cell of the antheridium, which like the vegetative

${ }^{1}$ Hanstein, Befruchtung und Entwicklung der Gattung Marsilia, in Pringsheim's Jahrbücher, iv. p. 197 .

2 1. c., p. 339 . 
cell has a small amount of granular content. The central part of the antheridium shows plainly the original bipartition, the sperm-cells being arranged in two groups. Numerous cases were observed(Fig.9a) which looked as if sometimes a sterile cell were formed within the central cell, although this appearance may have been due to the formation of a large intercellular space. At maturity the sperm-cells are much crowded, and so nearly fill up the antheridium, that at first sight there appear to be no peripheral cells; but a careful examination shows that they are not in immediate contact with the endosporium, but are separated from it by a more or less evident space. The capcell is also somewhat difficult to detect at this stage, but just before the antheridium opens it absorbs much water, and becomes then very conspicuous (PI. XIII, Fig. $14 \mathrm{c}$ ). Owing to the destruction of the starch through heating, the whole prothallium appears much more transparent than in life.

The mechanism of opening seems to be the same as in other Pteridophytes. The parietal cells absorb a great deal of water, becoming in consequence very turgid. At the same time the mucilaginous walls of the ripe sperm-cells also absorb water, increasing their volume thereby, and at the same time freeing the separate cells. The tension finally becomes so great that the wall of the antheridium is ruptured and the sperm-cells are forced out. The opening usually occurs between the cap-cell and the second parietal cell. As the internal pressure is removed, the parietal cells, in case they have not been ruptured, become much distended, and in the few cases where it was possible to free the empty antheridium from the spore, the parietal cells were found to project into the cavity of the antheridium, nearly filling it. Owing to the thinness of the walls the empty antheridium usually collapses, so that it is not easy to follow the outlines of the cells.

The presence of parietal cells in the antheridium of Pilularia corresponds with the later investigations in regard to other heterosporous Pteridophytes. Belajeff ${ }^{1}$ demonstrated the

\footnotetext{
${ }^{1}$ Belajeff, in Bot. Zeit., 1885 , pp. 793-809.
} 
presence of such cells in the antheridia of Isoëtes and Selaginella, and I called attention to the same fact in Salvinia!

In the study of the development of the spermatozoids chromic acid was used as a fixing medium, and the preparations were stained with haematoxylin. After removing the prothallium from the spore, it may be carefully crushed, and the sperm-cells thus separated. The nuclei are relatively small, but contain much chromatin, so that they color very intensely. The development differs in no wise from that of other plants studied by $\mathrm{me}^{2}$.

The nucleus becomes contracted on one side so as to appear somewhat crescent-shaped (Pl. XIII, Fig. I7). It rapidly elongates, becoming at the same time thinner and more homogeneous in appearance. As it elongates it winds about the cell close to the wall in the form of a delicate spiral band, having about two complete coils (Pl. XIII, Figs. 19, 20). It occupies but a small part of the cell, the greater part being taken up with central contents, including numerous relatively large starch-granules. The cilia appear to originate from the peripheral cytoplasm, as in other forms. The sperm-cells are still clothed with a delicate membrane at the time they are expelled from the antheridium, but this is soon completely dissolved and the spermatozoids escape. These are very small, and coiled in a nearly flat spiral about the upper part of the vesicle, which is derived from the central part of the mother-cell, and contains the starch-granules which occupied that position in the sperm-cell. On killing the spermatozoid with an iodine solution the body becomes deeply colored, and the cilia are then plainly seen (Pl. XIII, Fig. 2I). They are numerous, and relatively long and very delicate. Arcangeli ${ }^{3}$ states that there are but two cilia, but how he could have failed to see the others is hard to understand, as they are very easily demonstrated. The vesicle is very large, and becomes still more so by the absorption of water. Besides the starch-

1 Campbell, in Berichte der Deutschen botanischen Gesellschaft, 1887, p. 125.

2 Campbell, l. c., p. I 20.

3 l. c., p. 340 . 
granules, it often contains others that are not colored blue by the action of iodine. It is surrounded by a very delicate membrane that in some cases shows a bluish tint when treated with iodide of potassium.

Not infrequently the spermatozoid becomes entirely free from the vesicle, and then its coils separate and the spiral becomes elongated. This is always the case with those found about the open archegonium, the vesicle being held fast in the mucilaginous matter about its opening. The spermatozoids are often held in the mucilage in which the macrospore is imbedded, so that often one sees hundreds about the macrospore, not only in the vicinity of the open archegonium, but about the whole spore. It is true that the number is greatest about the open archegonium, which frequently becomes completely choked up with them; but only one reaches the oosphere, which thereupon becomes clothed with a cell-wall so as to effectually prevent the further entrance of spermatozoids. The basal walls of the neck-cells quickly turn brown, as an indication that fertilization is effected. Under normal circumstances it seldom happens that an archegonium fails to become fertilized.

In one case free spermatozoids were observed thirty-five hours from the time the spores were placed in water, but ordinarily from five to ten hours longer were necessary.

\section{The Macrospore and Female Prothallium.}

The structure of the macrospore of Pilularia has been so thoroughly studied, that no attempt will be made here to give more than a brief outline of the same. The spores are oval in form and white in color, quite large enough to be readily seen with the naked eye. About one-third the distance from the top is an evident constriction, above which the diameter of the spore is noticeably greater.

As already shown by the researches of Hofmeister ${ }^{1}$, Stras-

1 Hofmeister, Vergleichende Untersuchungen. 


$$
\text { of Pilularia globulifera, } L \text {. }
$$

burger ${ }^{1}$, Arcangeli ${ }^{2}$, and others, the wall of the spore is very complex.

On the outside is a mucilaginous layer that swells up greatly when placed in water. Below this is a very characteristic layer, showing a prismatic structure (P1. XIII, Fig. 23a). It is to the sudden thickening of this layer that the enlargement of the upper part of the spore is due. Within this two layers (Fig. 23. b, c) are further to be distinguished before the endosporium $(d)$ is reached. Of these the outer is thicker and presents a punctated appearance. Sections stained with safranin, or gentian-violet, show the structure of the wall of the spore very plainly.

Owing to the mucilaginous character of the outer coat, as well as the delicate character of the spore-contents, it is quite impossible to get satisfactory sections of the fresh spore, and recourse must be had to fixing agents. Various ones were used with good results, but on the whole absolute alcohol, in which the spores should be left for two or three days at least, was found the best. A I per cent. chromic acid mixture, and Flemming's mixture of chromic, acetic and. osmic acids were also successfully used, but care must be taken to thoroughly wash out the acids before further treatment.

In making the sections the spores were imbedded in paraffin, and then cut with a Cambridge rocking microtome. Schönland's methods ${ }^{3}$, with some simplifications, were used in most cases, but in others the spores were gradually brought into clove oil, and then into xylol instead of turpentine. This method requires little time, and often gives excellent results, but is not always to be relied on, though in the early stages it answered very well, and the penetration of the paraffin was facilitated. When chromic acid mixtures were used, the specimens were brought gradually into absolute alcohol, which was then replaced by clove oil, and finally by a saturated cold solution of paraffin in turpentine before being placed in the

1 Ban u. Wachsthum der Zellhäute.

2 l. c., p. 323.

3 Bot. Centralblatt, 1887, No. 22. 
melted paraffin. As a staining agent haematoxylin was used to some extent, but the best results were had with safranin and gentian-violet, the latter especially giving particularly beautiful coloring, the nuclei being much better differentiated than with the other colors ${ }^{1}$.

The spore is filled with protoplasm, in which are contained numerous starch-granules of various sizes, as well as oil-globules and granules of albuminous nature. The larger starch-granules are oval in form, and show more or less distinct concentric striation. Sections through the spores that have been treated with alcohol or some other fixing agent show a reticulated arrangement of the contents, and sometimes portions separate in the form of small vesicles, surrounded by a thin protoplasmic membrane. These vesicles probably represent vacuoles in the living spore. The upper part of the spore is filled with denser protoplasm, which also shows a reticulated structure, but with much finer meshes. This part (Plate XIII, Fig. 22) is almost completely free from starch-granules, and in the middle lies the nucleus, which is large and separated from the surrounding plasma by a clearly-marked membrane. It is discoid in form, strongly flattened above, and more or less undulate on the upper surface. Whether this latter peculiarity is in any way due to the reagents used cannot be determined, as it is quite impossible to make out the nucleus in the living spore. On account of its large size the nucleus is readily divided into sections in sectioning the spore, so that the interior structure is easily studied. It does not appear homogeneous (Plate XIII, Fig. 22 b), but is filled with numerous fine granules which act with reference to staining agents much like the surrounding protoplasm, and also form an indistinct net-work. The amount of chromatin is relatively very small, the chromatin-bodies being few and occupying only a very small part of the nucleus. They stain readily and deeply, the rest of the nucleus staining but little. No nucleolus was detected.

The spore, on being placed in water, begins to germinate

1 See Moll's article on the paraffin-imbedding process in the Botanical Gazette for January, 1888. 
in a very short time. The protoplasm at the top increases in volume, and begins to push out the inner spore-membranes, so that the upper part of the spore becomes decidedly more convex than at first (Plate XIII, Fig. 24). At the same time the nucleus becomes much more nearly globular, and the amount of chromatin is seen to be evidently greater, as well as to have become more evenly distributed (Plate XIII, Fig. 25). This stage was observed in sections made four-and-a-half hours after the spores were placed in water. At this time the appearance of the protoplasm in the upper part of the spore had also changed, having entirely lost the reticulated appearance which it has in the ungerminated spore.

This stage is figured by Arcangeli ${ }^{1}$, who did not, however, recognise the true nature of the nucleus, supposing it to be the beginning of the oosphere.

The youngest stage in which it was possible to demonstrate positively the first division in the spore occurred sixteen-anda-half hours from the commencement of germination. In this stage (Plate XIII, Figs. $26 a, b$ ) the primary nucleus had completely divided, and a transverse wall, $a$, had formed, cutting off the mass of protoplasm at the top of the spore from the rest of the spore. This wall does not always have the same form, being sometimes convex above, sometimes decidedly concave. The next wall to appear is nearly parallel with the first, and is completed within three or four hours from the time the first is formed (Fig. 27, $b$ ). A few cases were observed where this second wall did not seem to have been formed, so that the central cell of the archegonium was in direct contact with the first-formed wall, but this is exceptional.

Next are formed two walls in the upper cell, nearly perpendicular to the wall $b$, and meeting each other so as to enclose a nearly circular central cell. When seen from above (Plate XIII, Figs. 33, 34) these walls appear nearly semicircular and concentric with the periphery of the prothallium. The nearly circular central cell is the mother-cell of the archegonium.

\footnotetext{
1 1. c., Plate VII, Fig. 2.
} 
The prothallium (Plate XIII, Fig. 28) now consists of four cells, the discoid basal cell, $h$, the two peripheral cells, $p p^{\prime}$, and the central cell, $c$. As is usually the case, the mother-cell of the archegonium is distinguished from the other cells not only by its position, but also by its more densely granular protoplasm. The nucleus is also larger. It occupies the centre of the cell, and has a well-defined membrane. It is oval in form, and has chromatin-bodies of nearly round shape. A nucleolus does not seem to be present in most cases, though once a body was seen that may have been a nucleolus.

About the time that the mother-cell of the archegonium is formed, the basal cell undergoes division by a vertical wall into two nearly equal cells.

According to Arcangeli ${ }^{1}$ there is an almost regular concentric arrangement of the cells of the basal part of the prothallium, but numerous sections failed invariably to show anything approaching his figures. The first wall (Pl. XIII, Fig. 35, I) generally can be distinguished even after numerous divisions have taken place, and the radial walls, 2 , which succeed this can also frequently be traced in the later stages, but the number of these secondary walls is so variable, and the succeeding ones so very irregular, that beyond the first three or four divisions it is quite impossible to distinguish any regular succession in the order of division.

The order, so far as it can be traced, is as follows. After the first wall (P1. XIII, Fig. 35, I) is formed, a number of secondary walls, 2 , are formed running from the primary wall to the circumference but not strictly radial, and variable in number. The tertiary walls, 3 , run from the secondary walls to the circumference, and like these are usually somewhat curved. The next series of walls are tangential, but beyond this no regular order seems to prevail. In consequence of the variable number of the secondary and tertiary walls, as well as the subsequent differences in the arrangement of cells, the resulting cell-complex is extremely irregular, and differs widely in appearance in different individuals. The marginal 
cells undergo division by horizontal walls, but in the central part all the walls are vertical, so that the central cell of the archegonium, and later the embryo, are only separated from the cavity of the spore by a single layer of cells.

In the meantime the cells of the upper part of the prothallium have also been undergoing rapid divisions. In the peripheral cells are formed numerous radially placed vertical walls (P1. XIII, Fig. 34), so that the central cell, seen from above, appears surrounded by a single circle of small cells. The central cell next divides by a wall parallel to its outer surface (Pl. XIII, Fig. 29), the outer cell being the mother-cell of the neck of the archegonium, the inner one giving rise to the oosphere and canal-cells. The contents of all the peripheral cells are less uniform than those in the central cell, and the nuclei are much smaller.

The development of the archegonium proceeds as follows. The mother-cell of the neck becomes divided by two crosswalls into four equal cells, and soon after the central cell has a small discoid cell, the primary canal-cell, cut off at the top (Pl. XIII, Fig. 3I).

$U_{p}$ to this time, about thirty hours from the beginning of germination, the prothallium has increased but little in size and is still completely enclosed in the spore, and all the cells, including the central one, are very much flattened. A rapid growth in height now begins. The cells, which hitherto have been divided by vertical walls for the most part, now form horizontal walls, and at the same time increase in height, so that the young prothallium rapidly assumes its completed form. Each of the four primary neck-cells divides by a transverse septum into two, and the upper cells so formed project when full grown as a colorless papilla beyond the spore-membrane. As the neck increases in length the canal-cell elongates with it, and the ventral canal-cell is formed (PI. XIII, Fig. 32). It was impossible to get specimens where the nuclear division was taking place, which would of course determine the matter positively, but from the relative position of the walls in the canalcells one would certainly conclude that the ventral canal-cell 
arises here, at any rate, not by a further division of the central cell, but by division of the primary canal-cell. The wall dividing the two canal-cells is so high up, and so much shorter than the wall by which the primary canal-cell was separated from the central cell, that it is hard to see how such changes of position could be otherwise accounted for.

The divisions in the female prothallium are usually completed in from forty to forty-five hours from the time the spores are sown, and shortly thereafter the archegonium opens and is ready for fecundation. Owing to the opacity of the covering membranes, the only part of the archegonium that can be seen in the living prothallium is the upper part of the neck. The cells of this, as in other Pteridophytes, become much distended with water and diverge widely when the neck opens, and at the same time, as has been so often observed in other Archegoniates, the contents of the disintegrated canal-cells are forced out of the opening.

Fecundation takes place very soon after the archegonium opens, the spermatozoids, as already mentioned, collecting in great numbers about the open archegonium. The opacity of the spore-membranes makes it impossible to follow the spermatozoid to the central cell, but this probably takes place very quickly owing to the shortness of the neck. In nearly every case where the spores were placed in alcohol immediately after it was supposed that fecundation had been effected, the lower neck-cells had already begun to assume the dark-brown line indicative of the fact. In these cases the two nuclei could generally be demonstrated in the germ-cell.

The oosphere becomes almost at once surrounded by a membrane which prevents the further penetration of spermatozoids. As soon as the spermatozoid enters the germ-cell it appears to go through a similar series of changes, only in reverse order, to those which the nucleus of the sperm-cell undergoes in forming the spermatozoid. In the earliest stages observed, the elongated, more or less curved form of the spermatozoid was still indicated, but the body was less homogeneous than in the free spermatozoid. The body was also 


$$
\text { of Pilularia globulifera, } L \text {. }
$$

broader and shorter, indicating a separation of the chromatinmasses of which the body is composed. In all the later stages (Pl. XIII, Figs. $3^{8-39)}$ the spermatozoid, sp., had assumed much the appearance of an ordinary nucleus, nearly round in shape, and in close contact with the nucleus of the oosphere. The actual fusion of the two nuclei was not observed, but there is no reason to doubt that, as in other cases ${ }^{1}$ observed, the cavities of the two nuclei are thrown into direct communication, and that the contents of the male nucleus flow into the cavity of the female nucleus, thus completing the act of fecundation.

The nucleus of the oosphere (Pl. XIII, Figs. $3^{8-39}$ ) is large and has a well-marked membrane, but although a membrane may be present in the male nucleus, it is certainly much less evident, and it is by no means improbable, that a definite membrane is not developed.

The upper part of the oosphere, about one-third (Pl. XIII, Fig. $3^{8}$ ), is nearly transparent, and constitutes the so-called receptive spot. This is traversed by what look like continuations of the granular protoplasm of the lower part of the oosphere. The nucleus at this stage presents the appearance of a transparent vesicle, containing a faintly-marked net-work of fine filaments which do not stain readily, and a small amount of chromatin.

How long after the union of the two nuclei the first division in the fertilized germ-cell takes place could not be exactly determined, but it is probably within two or three hours, and possibly even sooner. In one case the germcell was observed undergoing division. In this instance (Pl. XIV, Fig. I) the daughter-nuclei were already complete, but the cell-wall was not yet complete. The nuclear spindle was still very evident, and in the middle lay the cell-plate, showing plainly the separate elements of which it was composed.

If for any reason the germ-cell fails to become fecundated the prothallium may continue to grow for some time, but this

'Strasburger, Ueber Kern und Zelltheilung im Pflanzenreiche, 1888, pp. 225-449. 
is by no means invariably the case. In no case, however, are new archegonia developed. Arcangeli's statement ${ }^{1}$ that the chlorophyll is developed independently of the action of light was confirmed. Spores were placed in water and removed at once to a dark place, where they were allowed to remain undisturbed for a week. At the end of this time young plants were found developed in a perfectly normal manner. They were slightly smaller, and the amount of chlorophyll may have been possibly rather less than in plants grown under normal conditions, but the difference was very slight.

\section{THE EMBRyo.}

The fertilized oosphere is not perfectly spherical, but more or less elongated transversely, and before the first division is completed this is strongly marked (Pl. XIV, Figs. I, 2). The first wall (basal wall) in the young embryo is approximately parallel to the axis of the archegonium, and divides the germcell into two equal cells (Pl. XIV,.Fig. 2). The youngest case where the completed division was seen was forty-six hours after the commencement of germination, but it is not improbable that it may occur somewhat earlier, as embryos only two hours older were observed in some cases (Pl. XIV, Figs. 6-8) to be already divided into numerous cells.

Of the two primary cells, one, as in the Polypodiaceae, gives rise to the first leaf and stem, the other to the root and foot. Of course, as the structure of the prothallium is radial, it is impossible to speak of an anterior and posterior cell at this stage.

The second or quadrant-wall (Pl. XIV, Fig. 3 II) follows as in other Pteridophytes, and divides the embryo into quadrants, the two upper being as a rule evidently larger than the lower ones.

In regard to the following divisions there is much difference of opinion, at least for Marsilia, which probably does not differ materially from Pilularia. Hanstein claims that the first wall in the embryo separates at once the stem and root, and that

$$
\text { - 1. c., p. } 336 \text {. }
$$


the subsequent divisions are to be looked upon as segments of these primary organs. Leitgeb and Arcangeli assert on the other hand that there is a regular formation of octants. My own observations do not confirm either view, but indicate that the quadrant-wall was the one which separated the primary organs, and that the quadrants are of equal morphological importance. In regard to the formation of octant-walls, while they are formed in the anterior quadrants, the corresponding walls in the root- and foot-quadrants form very unequal angles with the basal wall, so that the resulting cells are of unequal size. From this fact (see Pl. XIV, Figs. 5,6 ), it is possible to distinguish the primary organs of the embryo as soon as these walls are formed.

In order to avoid confusion it will be best perhaps to take up each quadrant separately and follow its development in detail.

\section{The LEAF.}

The leaf-quadrant, as already stated, undergoes division by an octant-wall into two entirely similar cells. Each octant now divides by a curved wall (Pl. XIV, Figs. 4-5), meeting basal and octant walls so as to form two cells, one retaining much the same form as the octant, that is tetrahedral, and appearing in section triangular; the other quadrilateral, as seen in section. The two tetrahedral cells function for a short time as apical cells, forming three series of segments corresponding to their lateral faces. Each segment next divides into an outer and an inner cell, from the former of which is derived the epidermis, from the other the ground-tissue and the vascular bundle. Sooner or later this apical growth ceases, and the growth is confined to the basal part of the leaf. The cessation of apical growth occurs about the fourth day, and before this the leaf begins to elongate (Pl. XIV, Fig. I6 a). Not infrequently one of the cells persists longer than the others, and can be detected after the leaf has assumed its conical form and become noticeably larger than the other members of the embryo (Pl. XIV, Fig. 15). In such cases the 


\section{Campbell.-On the development}

succession of the segments may be traced with little difficulty, whereas when no definite apical cell is present (e.g. Pl. XIV, Fig. 17 a), no such arrangement of the cells is distinguishable. The obliteration of the apical cell as such is brought about by a wall parallel to its outer face. The outer cell divides by vertical walls, soon becoming indistinguishable from the other epidermal cells, and the inner cell also dividing becomes part of the ground tissue of the leaf. About the end of the fourth day the leaf begins to grow much faster than the other members, and from this time onwards elongates with great rapidity. By the fifth day the differentiation of the future tissues is clearly indicated. A longitudinal section of the leaf at this stage (PI. XIV, Figs. I $7 a, b$ ) shows on the outside a single layer of nearly cubical cells, especially wellmarked near the apex of the leaf, which is somewhat pointed. This layer of cells constitutes the primary epidermis. Beneath it are usually about two layers of cells arranged in nearly straight rows, which converge towards the apex of the leaf. These cells give rise to the mesophyll, and at an early stage large intercellular spaces are formed between them. Within these is a conical mass of cells, the outer ones of which differ but little from those lying outside them, but the innermost ones have undergone division by longitudinal walls forming the beginning of the procambium of the future vascular bundle. This longitudinal division ceases at some distance from the point of the leaf, and in consequence the vascular bundle does not extend into it. The cells of the leaf-tip above the point where the procambium ceases increase enormously in size, elongating to many times their original length, and forming thus a very loose large-celled parenchyma that ultimately dies away. From this time the growth of the leaf is due entirely to the activity of the basal part. If we examine somewhat older embryos (P1. XIV, Figs. 22, 23) the differentiation of the young tissues is still more evident, and the limit between the actively dividing basal cells and the tip of the leaf is very conspicuous. If the base of the leaf of such an embryo as that figured in Fig. 23 is examined, it is usually 
found to be decidedly convex above, in consequence of more active growth on the upper side, and the young ground-tissue is much more strongly developed than on the ventral side, where there was but a single layer of cells separating the young epidermis from the young vascular bundle. The inner procambium-cells at this stage have increased considerably in length, and begin to show the pointed ends characteristic of the elements of the mature bundle, but no tracheids are yet distinguishable, these appearing first about the ninth day.

\section{The Root-quadrant.}

The first wall in the root-quadrant (Pl. XIV, Fig. 5) forms an angle of about $60^{\circ}$ with the basal wall, and thus divides the quadrant into two unequal tetrahedral cells. The larger of the two is the future apical cell of the root, and from the first it forms regular series of segments, but at the beginning only the lateral faces give rise to segments, that is, three series only are developed, the first segment of the root-cap being cut off only after about two complete sets of lateral segments have been formed (PI. XIV, Figs. 12-I6a). The apical cell of the root is from the first very conspicuous, and immediately recognizable as such. By the fourth day there have been two segments cut off from each lateral face of the apical cell, and the first segment of the root-cap has also appeared. The celldivision in the segments is very regular, and corresponds with what has been observed in other Pteridophytes. The first wall in the lateral segment (Pl. XIV, Fig. 20, I, II) is perpendicular to the broad faces of the tabular segment, and divides it into two nearly, but not quite, equal cells, as the wall does not extend quite to the centre, but meets one of the lateral walls a short distance above it. Each of the cells thus formed next divides by a tangential wall into an inner and an outer cell, the former giving rise to the cells of the plerome-cylinder, the latter to the epidermis and periblem.

An excellent idea of the succession of the divisions can be had by making a series of cross-sections through the tip of the 
root, but this is best done after the root has attained some length. Part of such a series is shown in Plate XV, Figs. 2-5, taken from an embryo of nine days. The younger segments, as will be seen on comparing them with those from a younger embryo (Pl. XIV, Figs. 20, 21), are much the same, but as the sections are made further from the tip of the root changes are observed which had not yet appeared in the younger embryo. The outer of the two original cells of each semi-segment divides by a tangential wall into two nearly equal cells, and these ultimately undergo further division by similar walls, the outer into two, the inner into three.

About the time that these cells are formed (Pl. XV, Fig. 3), intercellular spaces appear at the points where the inner and outer cells are in contact, and these appear larger and larger as the root increases in diameter. The two outermost layers, i.e. epidermis and hypoderma, undergo further radial divisions and form an uninterrupted double layer of cells, but the three original cells lying between the hypoderma and the pleromecylinder divide subsequently only by horizontal walls and form single rows of cells separating the large intercellular spaces. The older sections (Pl. XV, Figs. 4, 5) show a perfectly uniform radial structure. In the centre is a group of about nine cells, the young bundle, from which radiate at regular distances rows of three cells each. The lower cells of these rows are in contact and constitute the bundle-sheath, but the others are separated by the large intercellular spaces. Bounding the section are the two rows of cells forming epidermis and hypoderma.

The cell-division in the cap-segments is illustrated in Pl. $\mathrm{XV}$, Fig. $2 a, b$. In Fig. $2 b$ the central part shows the youngest cap-segment, the peripheral cells belonging to the next oldest segment. As seen here each segment-cell has divided into two nearly equal parts, and these, by walls at right angles to the first, also into approximately equal cells. These are next divided by tangential walls and the resulting marginal cells by radial walls, so that on section four central cells and a marginal circle of smaller ones are now visible (Fig. 2 a). These marginal cells later undergo further 
divisions, but only in two planes, there never being any horizontal walls formed, so that the segments of the root-cap form single layers of cells, and its stratified structure as scen in longitudinal section is very marked.

\section{The STEM-QUAdRANT.}

The stem quadrant, like that of the leaf, divides first by a regular octant-wall, and the resulting octants grow for a time in the same way. As in the root, the apical cells are distinguishable from the first, each octant in fact functioning as such from the beginning, and dividing by segments cut off in regular order from the three inner faces of the octant, which has the tetrahedral form that characterizes the apical cell of the older stem. The first wall in each octant (Pl. XIV, Fig. I I $y$ ) meets octant-and quadrant-walls, and cuts off a large cell which is in contact with the foot, and according to Hanstein and Arcangeli is to be regarded as part of the foot. That physiologically this is the case is indisputable, as these cells, lying as they do next the basal cells of the prothallium, must help to absorb the nutriment from the spore. As, however, these segments are cut off from the stem-quadrant, and not from the foot itself, and are in all essential particulars both in regard to form and methods of division like the later segments, it seems more in accordance with the facts to regard these segments, morphologically at least, as the first segments of the stem and second leaf, and the equivalent of the later ones.

Hanstein's statement that the first wall in the stem-quadrant of Marsilia corresponds to the wall in the accompanying figures, and that the octant-wall is formed subsequently, is not confirmed by later observers, nor was it found to occur in any instance observed by me in Pilularia.

Of the two octants, one becomes the stem and the other the second leaf, corresponding with the earlier observations of Hanstein and Arcangeli. These are often not to be distinguished from each other for some time, but as a rule the 
divisions in the leaf-octant are less regular, and very often the apical cell becomes obliterated at an early period (PI. XIV, Fig. $16 c$ ).

There seems to be no rule as to which of the octants of the stem-quadrant forms the apical cell of the stem, as it was found in about an equal number of cases to be right or left. The succession of segments cut off from the apical cell proceeds from the outside towards the octant-wall, the three segments of each series being respectively approximately parallel to the quadrant-, basal, and octant-walls. The direction of the leaf-spiral, which depends upon the arrangement of the segments, will of course be determined by the position of the original stem-octant with reference to the octantwall. Kny ${ }^{1}$ comes to similar conclusions with reference to the establishment of the leaf-spiral in Ceratopteris.

Each segment divides by a tangential wall into an inner and outer cell, the former dividing again by a similar wall and the latter by a radial wall, so that a vertical section through the young segment at this stage (Pl.XIV, Fig. I 8) shows four cells, two inner and two outer ones. The inner cells undergo repeated division in all directions, but the outer ones only by radial walls.

The stem grows very slowly at first, and by the time the first leaf and root have attained length enough to break through the prothallium, the stem shows only about two completed series of segments. Even at this stage (Pl. XIV. Fig. 23) the inner cells of the segments have rapidly divided and the first traces of the vascular bundle are distinguishable.

The first segments are larger than the succeeding ones, and the broadly tetrahedral form of the original octant is thus rapidly reduced to the much narrower form of the apical cell of the older stem.

The octant which does not become the apical cell of the stem, forms, as we have seen, the second leaf of the plant. In a certain sense, assuming that the quadrant-wall establishes

1 Kny, Die Entwicklung der Parkeriaceen, in Nova Acta Acad. Leopold. xxxvii, No. 4 , p. 58 . 
the primary members of the embryo, we may say that the second leaf originates like the later ones, as a segment of the apical cell of the stem. Like the stem, it grows slowly at first, and in case the apical cell persists, is scarcely to be distinguished from it (PI. XIV, Fig. $22 d, l^{2}$ ). About the eighth day, however, it begins to elongate, though much more slowly than the primary leaf, and from this time onwards is very easily recognised (Pl. XIV, Fig. 25 ; Pl. XV, Figs. I, 8). About two weeks after sowing the spores the second leaf begins to grow rapidly, and in a very few days reaches its full size.

\section{The Foot-quadrant.}

The first divisions in the foot-quadrant (Pl. XIV, Figs. 8, 9, \&c.) follow closely those of the root, but this regularity soon ceases, and after the first two or three divisions no definite succession of the walls can be distinguished. The foot never attains any great size, and as already said, all the lower cells of the embryo probably absorb the nutriment from the spore.

As the embryo grows the prothallium keeps pace with it for some time. About the time the embryo is divided into eight cells, the upper part of the archegonium has its cells divided by tangential walls, so that this part of the embryo is surrounded by a double layer of cells (Pl, XIV, Figs. Io, I3). Both Hofmeister and Arcangeli ${ }^{1}$ figure this condition in the unfertilized archegonium, which in Pilularia never occurs.

The basal cells of the prothallium divide further and develop numerous root-hairs. The plasma in the upper part of the spore increases in quantity as the embryo develops and pushes up the base of the prothallium and embryo, which become in consequence strongly concave below (Pl. XIV, Fig. 23). Although the nucleus was not observed in actual division, in a number of instances in the later stages of development bodies which behaved with reference to staining agents in the same way as nuclei were seen in this plasma-mass, and were quite probably derivations of the original 'endosperm nucleus.'

\footnotetext{
${ }^{1}$ l. c., Plate VIII, Fig. 5.
} 


\section{The Structure and Division of The Nuclei IN THE EMBRYO.}

Owing to their small size the nuclei of the embryo are not well adapted for the study of nuclear division. Except during the actual division the nuclear membrane is well defined. With safranin, or better with gentian-violet, the chromatin stains very intensely, the same treatment being used as recommended by Moll for the root-tips of Phanerogams ${ }^{1}$. In the actively growing embryo all stages of division may be found. As elsewhere, the amount of chromatin increases very perceptibly at the time of division, the resting nucleus showing but a small amount of chromatin, and the chromatin-masses being extremely small and scattered. A small nucleolus can generally be seen. A stage was observed (P1.XIV, Fig. 28) which was not thoroughly understood. A pparently a single relatively large and intensely coloured body was present. This was so small in some cases as to be readily taken for a nucleolus, but usually it was larger, and when sufficiently magnified did not appear perfectly homogeneous; all intermediate forms between this and others where numerous chromatin-masses were present could be readily found, and led to the conclusion that the apparently single mass is in reality composed of closely apposed, but not united chromatin-bodies, which subsequently separate more widely previous to the division of the nucleus. The chromatin-bodies are short, and with ordinary lenses appear like round granules, but when more strongly magnified are seen to be somewhat elongated.

After they have completely separated a nuclear spindle is formed, the nuclear membrane having disappeared, and the division proceeds in the usual manner. The segments now undergo division, as is indicated by the evidently greater number of segments forming the nuclear plate (Pl. XIV, Fig. 29a), but owing to their extreme minuteness it is quite impossible to make an exact computation of their number.

\footnotetext{
1 1. c. on page 244
} 


$$
\text { of Pilularia globulifera, } L \text {. }
$$

\section{Subsequent Growth of the young Plant.}

After the eighth day the first leaf grows with great rapidity, and soon reaches its full size, breaking through the overlying prothallium-cells about the ninth day. All the cells elongate very much, and in the ground-tissue are developed large intercellular spaces forming air-passages very similar to those in the root, but less systematically disposed. They are separated by single layers of cells, radially disposed, so that a crosssection (Plate XV, Fig. 6) presents the same wheel-shaped appearance that is observed in a similar section of the root. Small intercellular spaces are also formed later between the outer cells of the hypoderma. There is only one vascular bundle, and this is of a very simple character. It is surrounded by a bundle-sheath of small cells, whose walls color more intensely than those of the mesophyll. The rest of the bundle is composed of narrow cells, with more or less pointed ends, and no intercellular spaces. At two or three points are developed small spirally-marked tracheids, which are the first to be developed in the young plant. The first signs of the thickenings in their walls is evident about the ninth day, that is, about the time that the young plant breaks through the prothallium.

The epidermis consists, as is usual in leaves of this form, of very much elongated cells. As in ferns, there is some chlorophyll formed in the epidermal cells. The stomata (Plate XV, Figs. 12, I3) are few in number and of simple structure.

The second leaf (Plate XV, Fig. 8), and the succeeding ones, exhibit perhaps more frequently than the first the growth by an apical cell. This develops three series of segments, each of which divides first into an inner and an outer cell, the first forming the young epidermis, the other the mesophyll and vascular bundle, which develop in the same way as in the first leaf.

About the time that the first tracheal tissue is distinguishable, the second root is formed at the base and on the under side of the first leaf. The apical cell is formed at some distance below the surface, and the root begins to grow at 
once by means of segments cut off from it in the same way as the primary root. The first trace of the vascular bundle is formed at a point in immediate contact with that of the leaf (Plate XV, Fig. 7), and its development proceeds from this point toward the apex of the young root.

The apex of the stem grows slowly, producing from time to time a complete set of segments in rapid succession, and then resting for some time before another set is formed, so that there is always considerable difference in the ages of any two succeeding sets of segments; and as the segments divide rapidly after being formed, if the apex of an older plant is examined (P1. XV, Fig. 9), while the youngest set of segments may be perfectly plain, it is not easy to trace the limits of the older ones. From the slowness with which new segments are formed, and the crowded manner in which the young leaves are arranged, it is probable that each segment gives rise to a leaf, or rather that the two dorsal segments of each set form leaves, while the third, or ventral segment, gives rise to a root, at least the regular occurrence of roots in relatively the same position to the apical cell of the stem, as the young leaves would indicate that this is the case (Pl. XV, Fig. 9r). All the roots however cannot be thus formed, as their number exceeds that of the leaves, and it is highly probable that the others originate from the bases of the leaves in the same way as the second root.

Owing to the rapid growth of the young leaves, and the slowness of that of the apex of the stem, the latter becomes more and more sunk, until after three or four leaves are completely grown it scarcely projects at all. The younger portions of the stem and leaves are more or less covered with short-jointed hairs, which also covered the growing-point of the stem to a certain extent. The elongation of the stem is due almost entirely to intercalary growth of the older segments.

The first leaves show scarcely a trace of the coiling that characterizes the young leaves formed later, but this becomes more and more evident as the plant grows. 


\section{The Relationships of the Marsiliaceae.}

Botanists have long recognized the evident relationship of the Marsiliaceae to the true ferns, especially to the Polypodiaceae, and this view is strengthened by the very great resemblance in the structure of the antheridium. Whether a more complete knowledge of Salviniaceae will show further relationships between them and the Marsiliaceae is doubtful, for apart from both families being heterosporous, they have little in common.

In conclusion I beg to express my sincere thanks to Professor Kny, in whose laboratory the investigations were made, both for his valuable assistance and also for the great interest he has taken in the work from the time it was begun.

BERLIN, June, I888.

\section{EXPLANATION OF FIGURES IN PLATES XIII, XIV, AND XV.}

Illustrating Mr. Douglas H. Campbell's paper on the Development of Pilularia globulifera, $L$.

\section{PLATE XIII.}

Figs. I-11. Successive stages in the development of the male prothallium and antheridium of Pilularia globulifera. Figs. $4 c, 6,7$, and to $b$ are seen from above; the others are optical longitudinal sections. Fig. 7 is from a preparation fixed with Flemming's mixture, the others are chromic acid-preparations. All were stained with haematoxylin and mounted in dilute glycerine. $x$, the second cell of the prothallium. $\times 37.5$.

Figs. 12, 13. Ripe antheridia removed from the spore by heating. Fig. I 2 stained with haematoxylin and mounted in glycerine; Fig. I 3 uncolored and examined in water. $\times 375$.

Fig. 14. A living microspore which is on the point of discharging the spermatozoids. $c$, the cap-cell of the antheridium distended with the water it bas absorbed. $\times 375$.

Fig. I5. A partially emptied antheridium removed from the spore by heating. $\times 375$.

Figs. 16-20. Successive stages in the development of the spermatozoids. Chromic acid-haematoxylin-preparation. The starch-granules have been mostly destroyed by heating, but in Fig. 20 traces of them are still to be seen. Leitz oil-immersion, $\frac{1}{16}$. 
Fig. 2 I. Free spermatozoids, $a$ from above, $b$ from the side; colored with iodide of potassium. $v$, the vesicle with the included starch-grains. $c$, alcohol-gentianviolet-preparation. $d$, a vesicle from which the spermatozoid has become free. Leitz oil-immersion, $\frac{1}{1} \sigma$.

Fig. 22. $a$, Longitudinal section through an ungerminated macrospore. $\times 90$. $b$, The nucleus of the same examined with a $\frac{1}{10}$ oil-immersion. Alcohol-gentianviolet-preparation.

Fig. 23. A section through the wall of the macrospore. $\times 300$. Alcoholsafranin-preparation.

Fig. 24. Longitudinal section throngh a macrospore $4 \frac{1}{2}$ hours after being placed in water. Flemming's mixture-haematoxylin-preparation.

Fig. 25. The nucleus of a spore of the same age, but colored with safranin and examined with a $\frac{1}{16}$ oil-immersion.

Fig. 26. Two sections through a spore I61 hours after the commencement of germination. $x$ about roo. Alcohol-haematoxylin-preparation.

- Fig. 27. The first wall is completely formed. In $a$ is shown the nucleus of the mother-ceil of the prothallium, in $b$ that of the spore.

Figs. 27-32. Successive stages in the development of the female prothallium and archegonium, $\times 300 . \quad a$, the first wall. $b$, the second wall. $c$, the primary canal-cell. Figs. 27, 3I, 32, alcohol-gentian-violet-preparations; Fig. 28, alcoholsafranin; Fig. 29, Flemming's mixture-safranin ; Fig. 30, chromic acid-safranin.

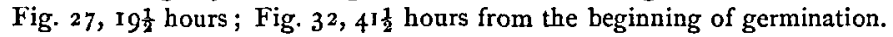

Fig. 33. Cross-section of a prothallium 24 hours old. $c$, mother-cell of the archegonium. $p, p^{\prime}$, peripheral cells. Alcohol-gentian-violet-preparation. $\times 300$.

Fig. 34. A similar section to Fig. 33, but somewhat further advanced.

Fig. 35. Cross-section of the basal part of a young prothallium. The succession of the walls is indicated by the numbers. Alcohol-gentian-violet-preparation. $\times 300$.

Fig. 36. A similar section from a full-grown prothallium. Alcohol-Bismarckbrown-preparation.

Fig. 37. A section through the neck of a full-grown archegonium. AlcoholBismarck-brown-preparation. $\times 300$.

Figs. 38,39 . Sections through archegonia in which fertilization has recently taken place. Fig. $3^{8}$ a longitudinal, Fig. 39 cross-section. $s p$, the male nucleus. In Fig. 38 several spermatozoids are seen about the neck of the archegonium. Alcohol-gentian-violet-preparation. $\times 300$.

\section{PLATE XIV.}

Fig. 1. Transverse section of the fertilized germ-cell undergoing the first division. Alcohol-safranin-preparation. $\times 300$.

Fig. 2. Longitudinal section of a somewhat more advanced stage, in which the first division is complete. This and the succeeding figures, unless otherwise stated, were drawn from preparations fixed. with absolute alcohol, and colored with gentian-violet, and magnified 300 diameters. 
Fig. 3. Vertical section through an embryo composed of four cells. The first wall (basal wall) is here and in the succeeding figures indicated by the number $\mathbf{I}$, the second (quadrant-wall) by II. The direction of the arrow indicates the anterior end of the embryo.

Fig. 4 vertical, Fig. 5 transverse section through somewhat older embryo. Fig. 4, alcohol-borax-carmine-preparation. Fig. 5, alcohol-safranin-preparation.

Figs. 6-8. A series of three transverse sections throngh a very advanced embryo $4^{8}$ hours after sowing the spores. l, leaf-quadrant; $r$, root; $s$, stem; $f$, foot.

Fig. 9. Series of four vertical sections through an embryo three days from the commencement of germination.

Figs. 10, II. Two vertical sections through an embryo of four days ${ }^{1}$.

Fig. 12. A similar section, but showing better the apical cell of the root.

Fig. I3. Median transverse section through an embryo of four days.

Fig. 14. Two other sections of the same embryo. $a$, above; $b$, below the quadrant-wall.

Fig. 16. Three transverse sections of an embryo of four days, but somewhat further advanced. The apical cell of the root has already formed the first cap-cell.

Fig. 15. A still more advanced embryo. Vertical median section.

Figs. I7-21. Series of vertical sections through an embryo of five days. Fig. 17, the leaf. Fig. 18 , stem. Figs. 19-21, root. In $17 b$ may be scen the beginning of the vascular bundle of the leaf.

Fig. 21 $a$. Longitudinal section through the root of an embryo of the same age.

Fig. 22. Series of four transverse sections of an embryo of seven days (not as far advanced as usual). In $b$ and $c$ are seen the indications of the vascular bundles of the root and leaf.

Fig. 23. Median longitudinal section of an embryo of eight days, still surrounded by the prothallium-cells and showing the macrospore. $x$ about 100 .

Fig. 24. The basal part of the same embryo. $\times 300 . \quad i$, intercellular spaces. $r$, apex of the root. $s$, apex of the stem.

Fig. 25. Second leaf of the same embryo.

Figs. 26-29. Details of the structure and division of the nuclei of the young embryo. All examined with a $\frac{1}{18}$ oil-immersion lens. Fig. 26 from a two celled embryo. Fig. 27, embryo of four days. Fig. 28, embryo of five days; alcoholsafranin-preparation. Fig. 29, embryo of eight days.

\section{PLATE XV.}

Fig. 1. Transverse section through the apex of the stem of an embryo of nine days. a, apical cell of the stem. $L^{2}$, the second leaf. The vascular bundle of the first leaf lies above. $\times 300$. Alcohol-gentian-violet-preparation.

Figs. 2-5. Series of transverse sections through the root of an embryo of the same age. $a, b$, sections through the root-cap, the others through the root itself. $i$, intercellular spaces. Alcohol-Bismarck-brown-preparation. $\times 300$.

1 The expressions four days, five days, etc., will be understood to mean from the time the spores were first placed in water. 


\section{Campbell.-On Pilularia globulifera, $L$.}

Fig. 6. Transverse section near the base of the first leaf of an embryo nine days old. $i$, intercellular spaces. Alcohol-gentian-violet-preparation. $\times 300$.

Fig. 7. Vertical section of an embryo thirteen days old showing the second root. $R^{2} . \quad \times 300$.

Fig. 8. The second leaf of the same embryo. $\times 3$ zoo.

Fig. 9. Longitudinal section through the apex of a young plant that had four fully-developed leaves. $s$, Apex of the stem. $L, L^{1}$, young leaves. $r$, a young root. $x$ about 100 .

Fig. 10. Transverse section of a leaf of the same embryo. $\times 48$.

Fig. Ir. Vascular bundle of the same. $\times 300$.

Figs. I 2-I3. Stomata from the first leaf. $\times 300$. Fig. 12 in longitudinal optical section Fig. 13 from the surface. 

Annals of Botany
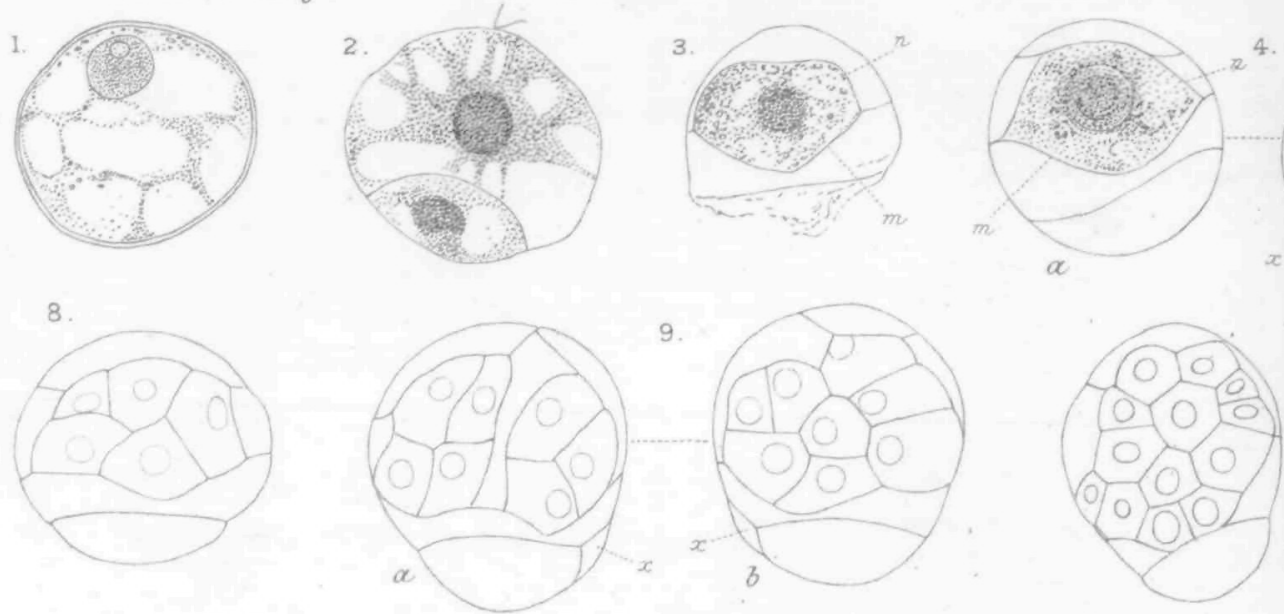

9.
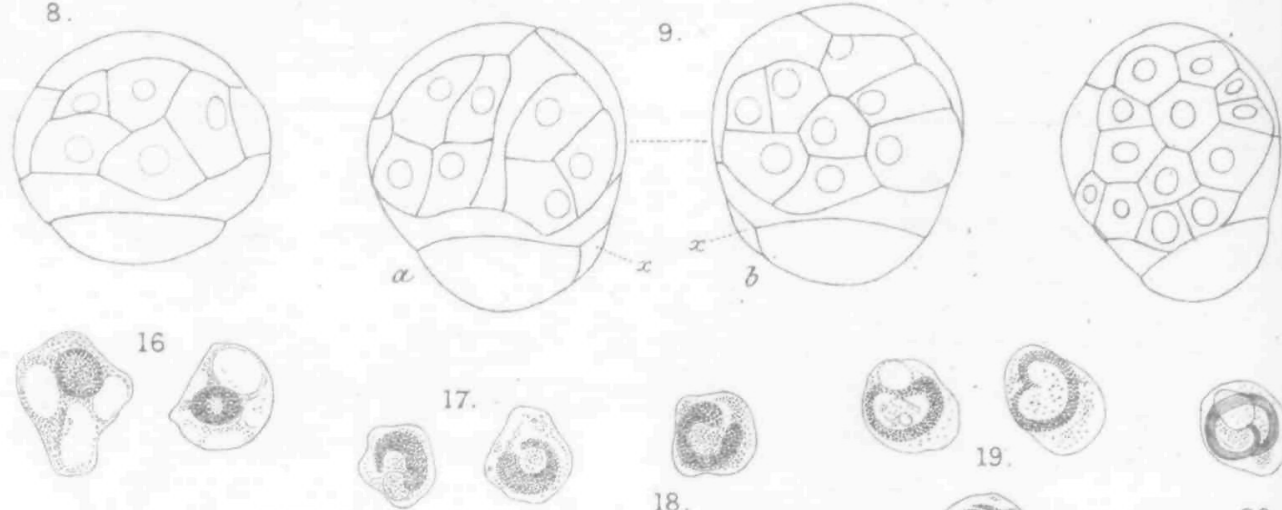

18.
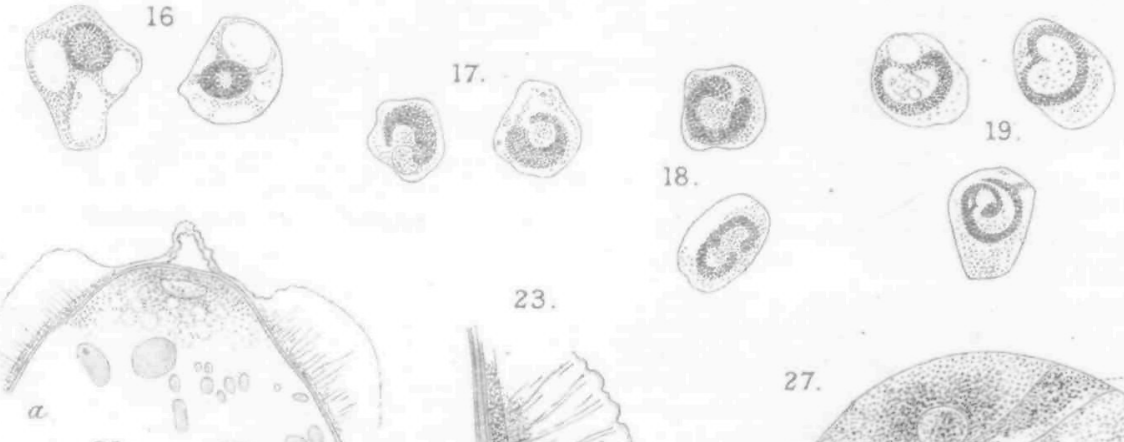

19

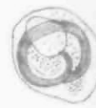

23.
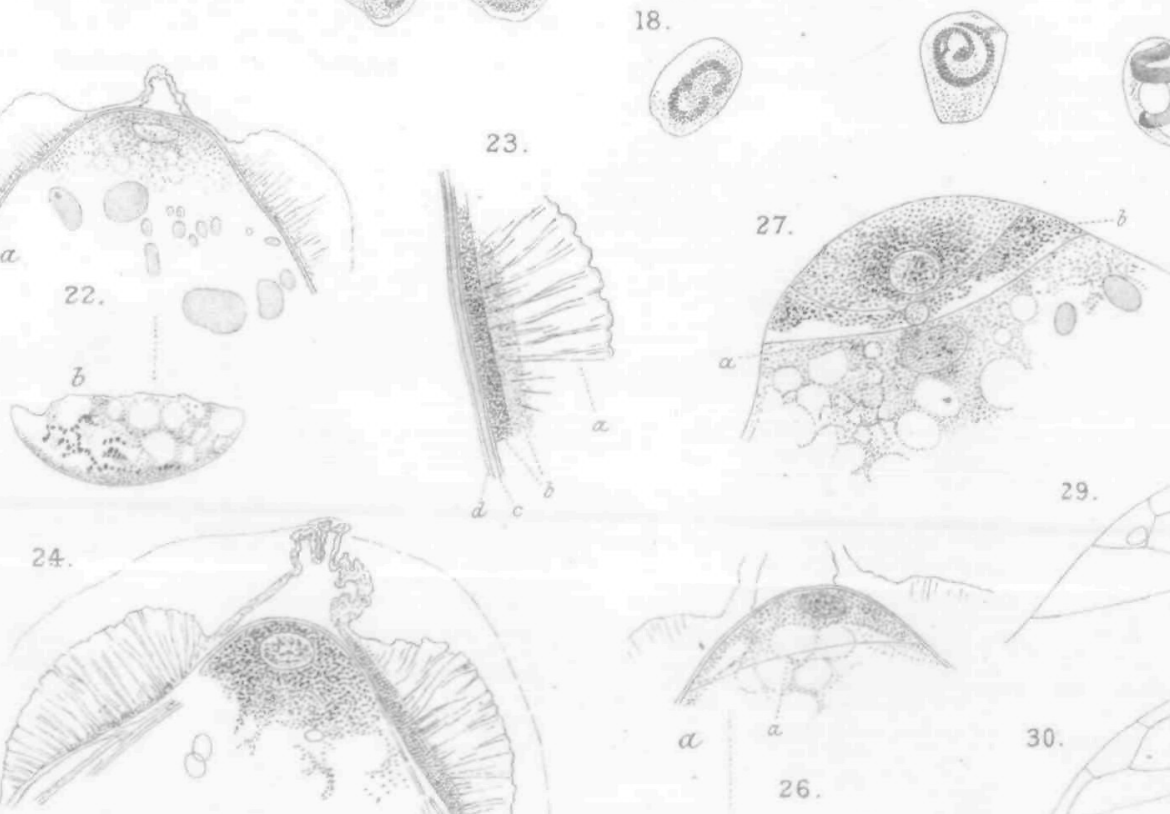

25
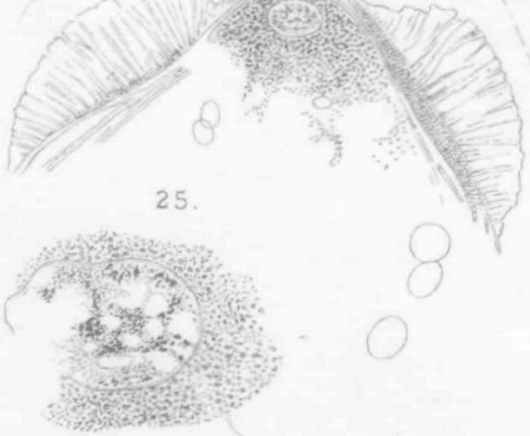

D H. Campbell de?

$$
\text { CAMPBELL. - DEVELOPMENT OF PILULARIA GLOBULIFERA. }
$$


Vol. II, PL. XIII.

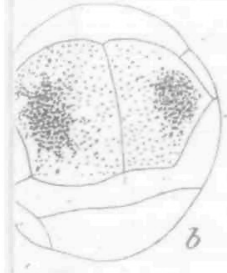

10.

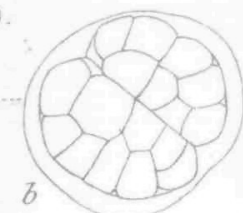

$\sqrt{(0)} x$

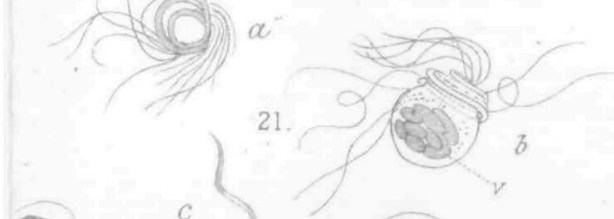

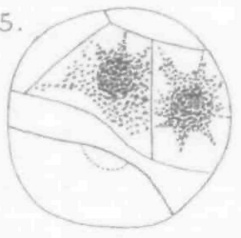

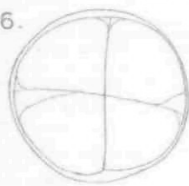

12

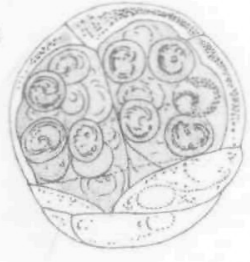

${ }^{13}$

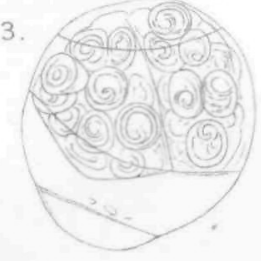

7.

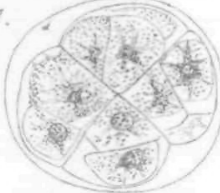

14

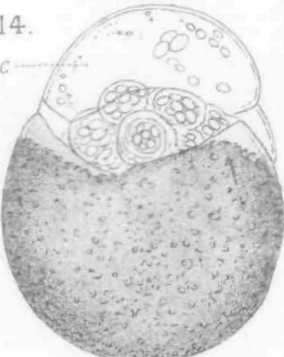

15.

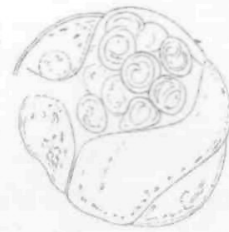

(2) ร

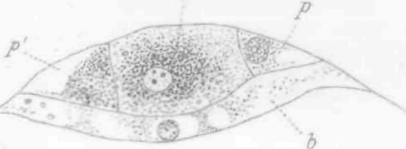

28.

33.
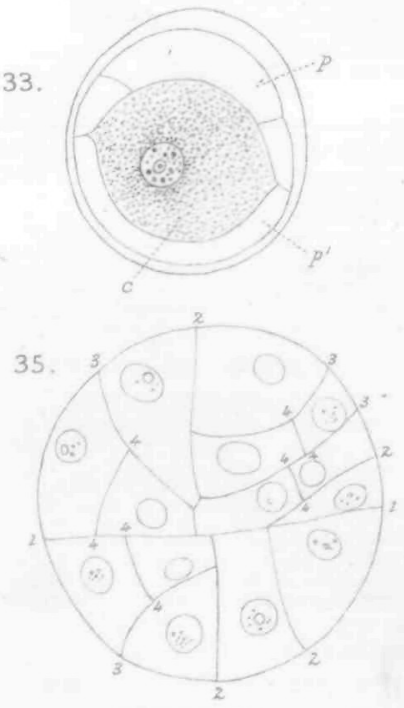

32.

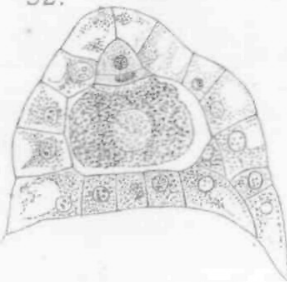

37.

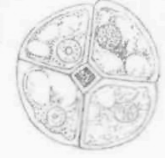

39

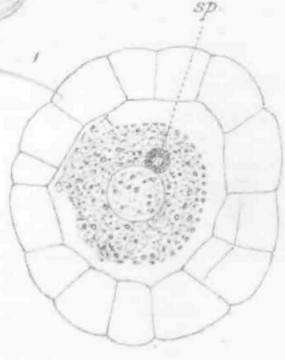

38.

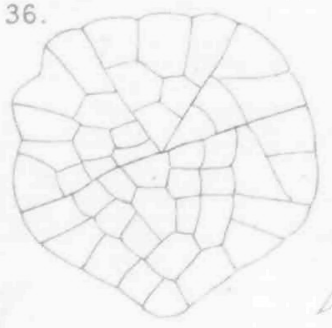




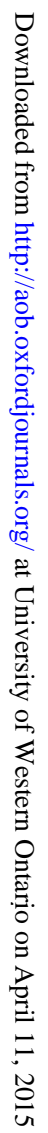

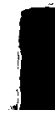



Annals of Botany

1.

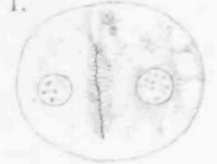

3.
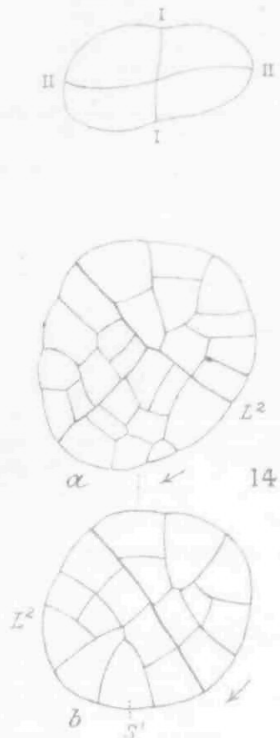

18.

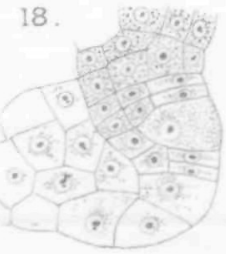

19.
2.

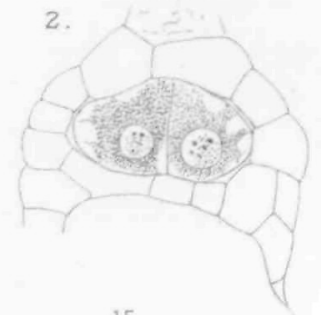

15.

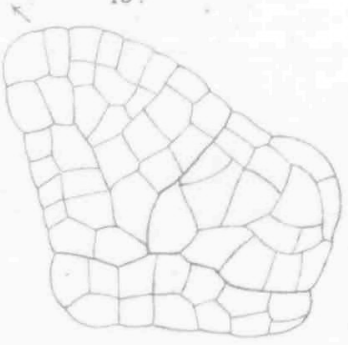

5.

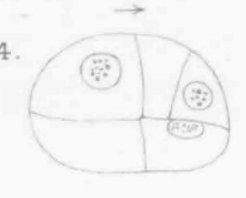

4.

9.

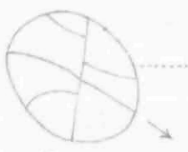

a

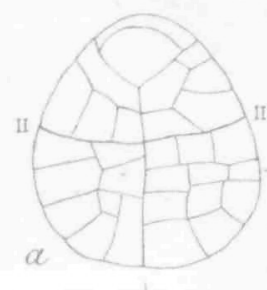

16.
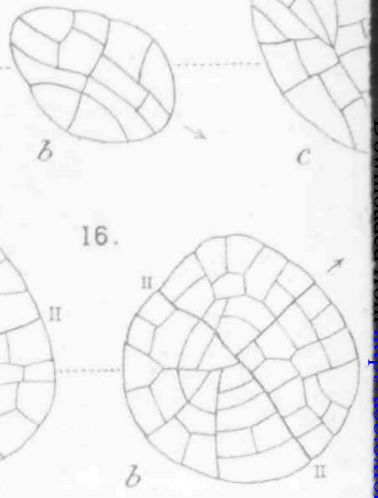

6.
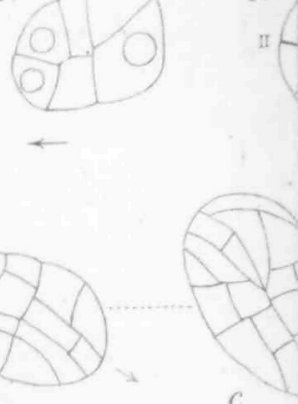

c

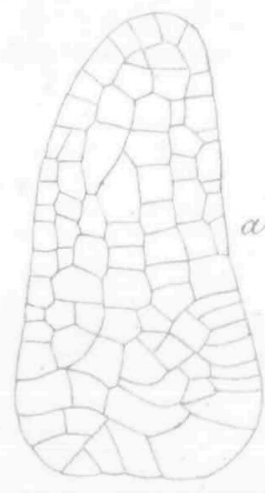

20

17.

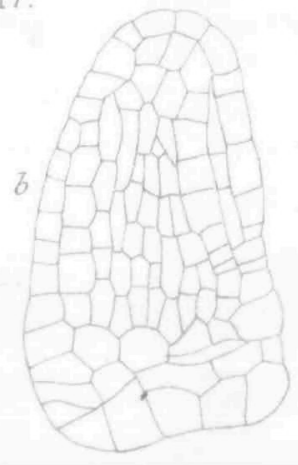

21.
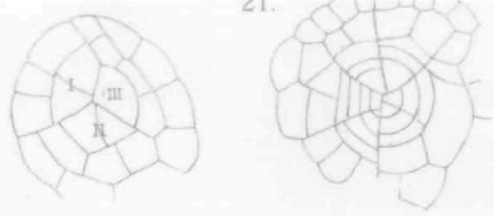

23.

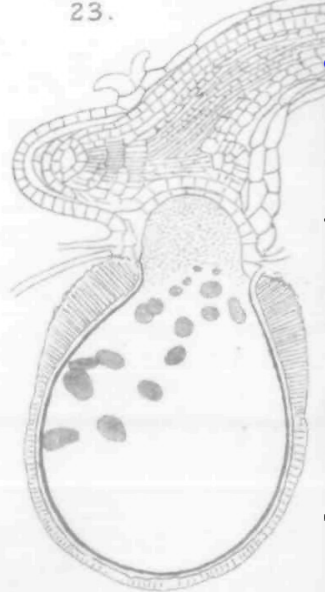

27.

28.

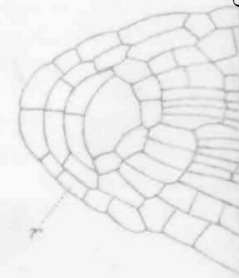

26.

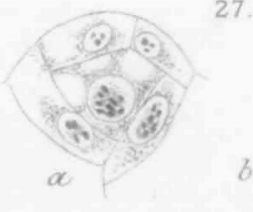

D il Campbell del.

CAMPBELL. - DEVELOPMENT OF PILULARIA GLOBULIFERA. 
VoL.II, PU. XIV.
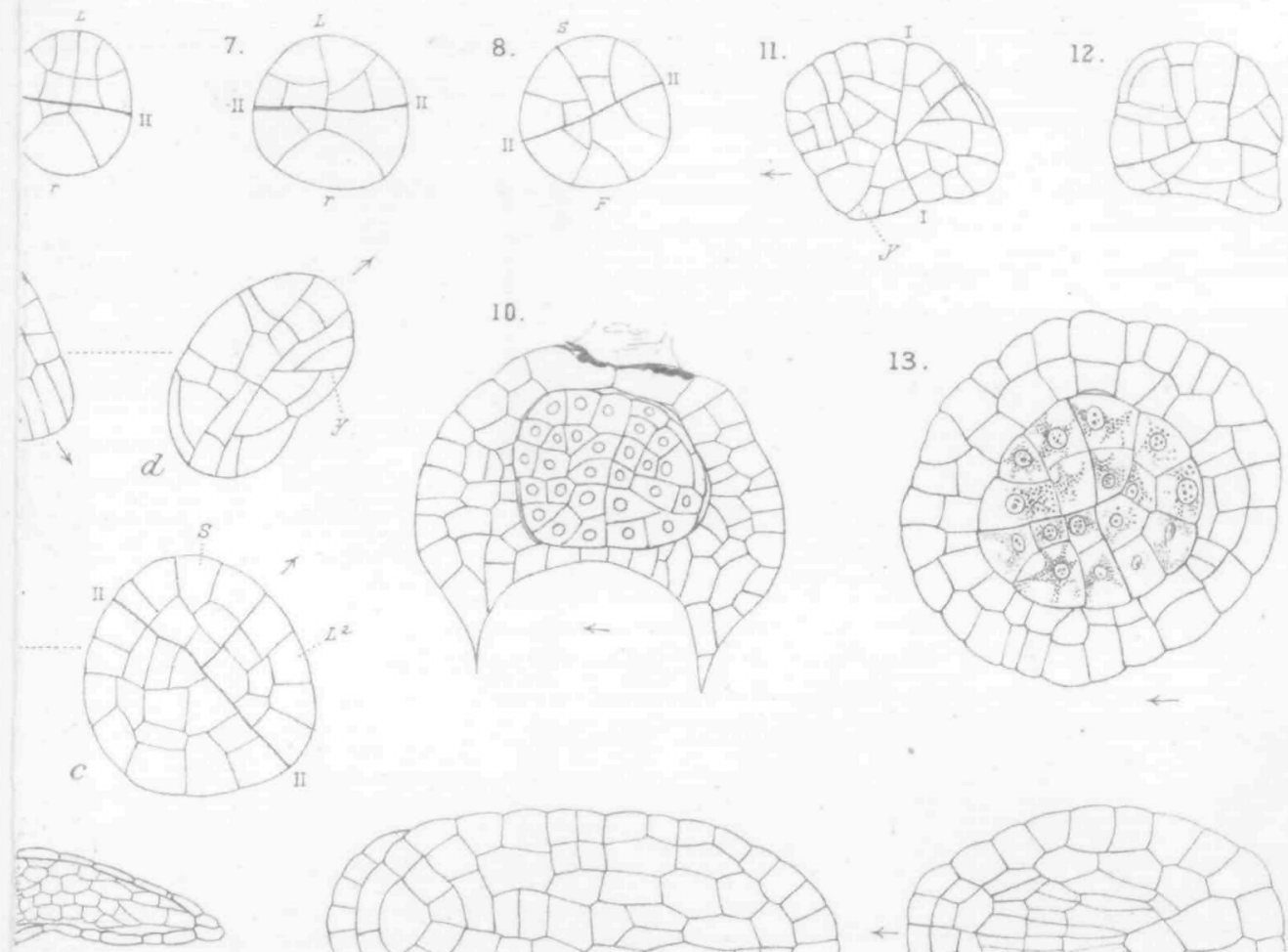

$21^{a}$

अध
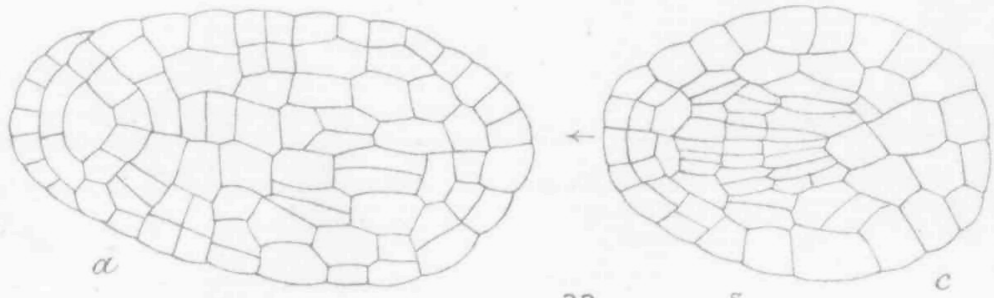

(9)

22.

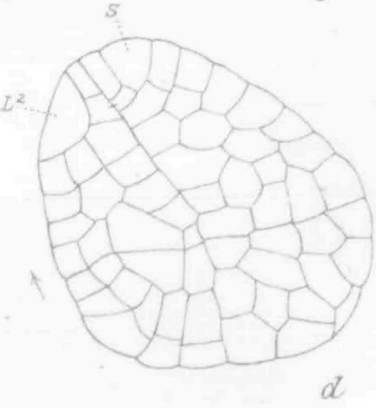

29.

25.
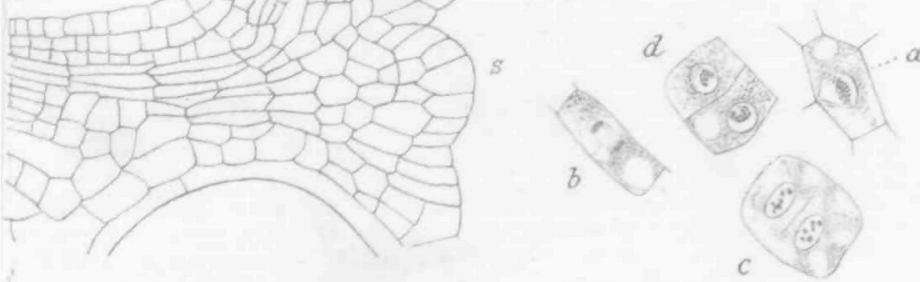

University Press, Oxford 


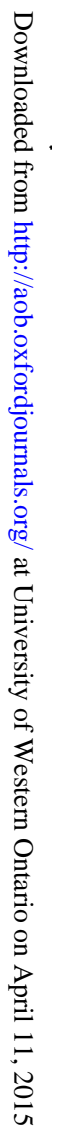

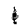




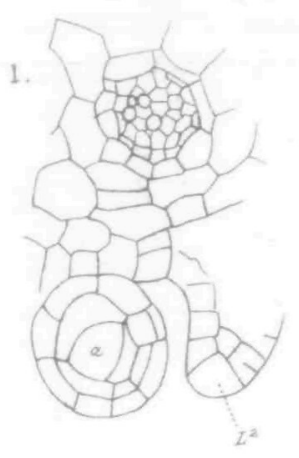

4.
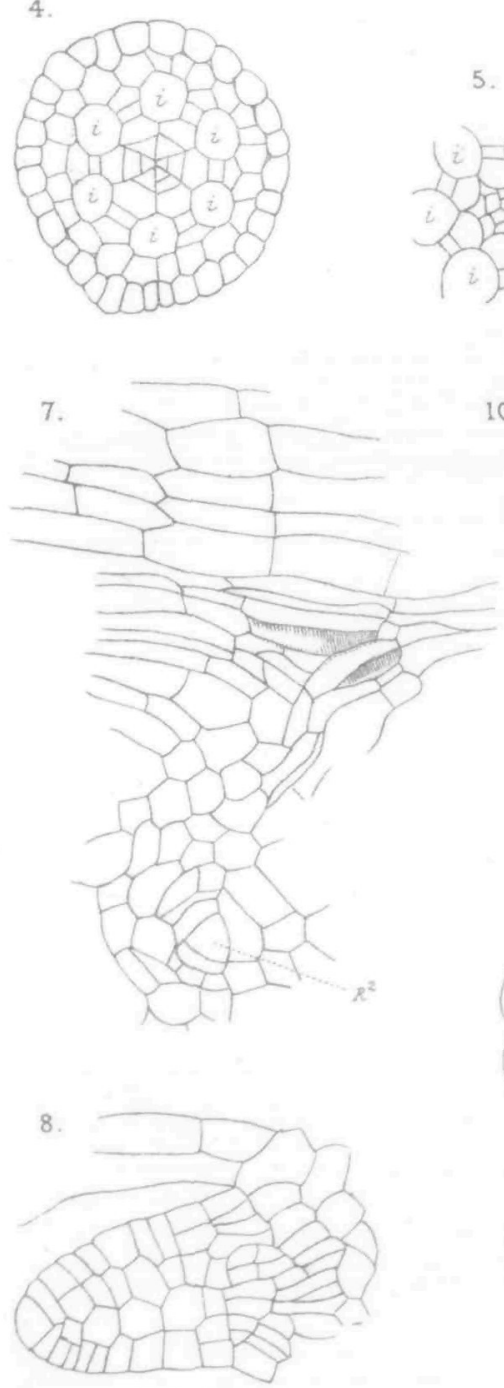

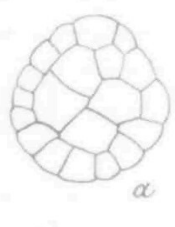

2.
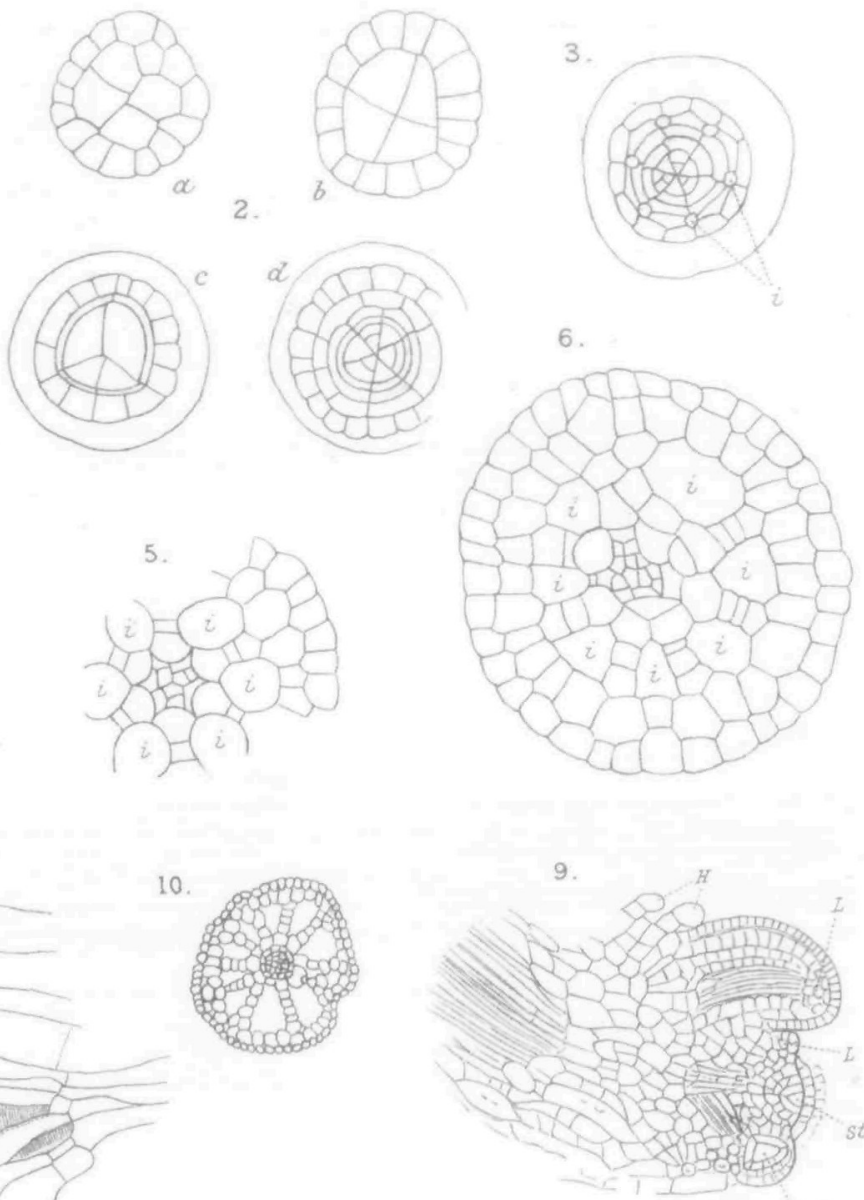

11
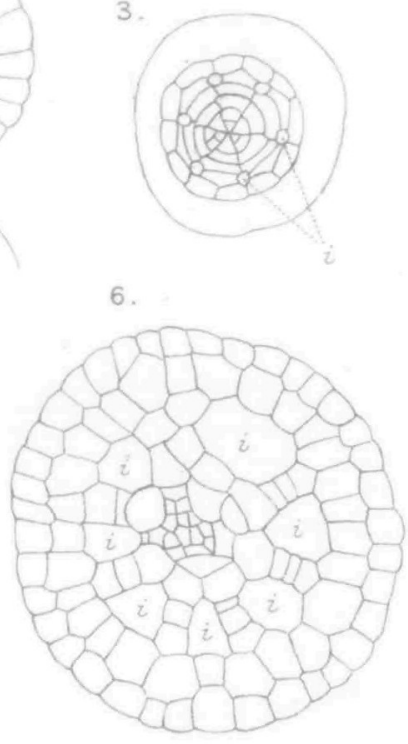

6.

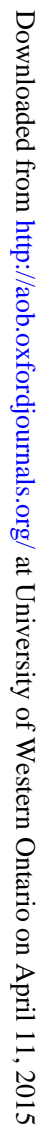

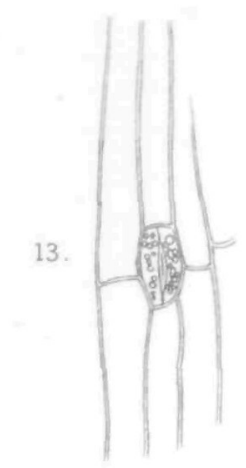

University Press, 0xford.

D. H. Campbell del.

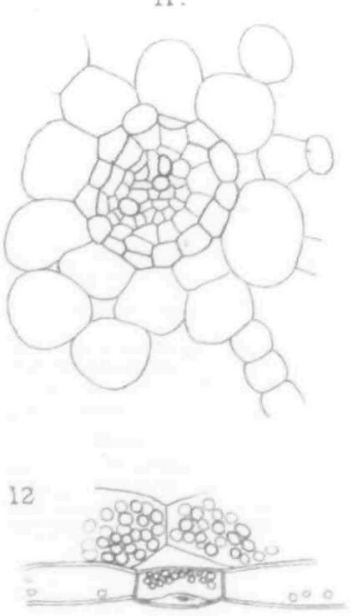

CAMPBELL. - DEVELOPMENT OF PILULARIA GLOBULIFERA. 
